\title{
Effect of Culture M edium Supplementation with b-mercaptoethanol and A mino A cid on Canine Intergeneric Embryo Development with Porcine Oocyte Cytoplasm Recipient
}

\author{
Yuda Heru Fibrianto
}

Department of Physiology, Faculty of Veterinary M edicine, Gadjah Mada University, Yogyakarta 55281, Indonesia.

\begin{abstract}
The present study investigated the effect of culture medium supplementation with b-mercaptoethanol (b-ME) and amino acid (AA) on canineintergeneric embryo development with porcineoocyte cytoplasm. Porcine cumulus oocyte complexes (COCs) were collected from slaughterhouse and matured in TCM-199 supplemented with 26.2 $\mathrm{mM} \mathrm{NaHCO}, 3.05 \mathrm{mM}$ glucose, $0.91 \mathrm{mM}$ sodium pyruvate, $0.57 \mathrm{mM}$ L-cysteine, $75 \mathrm{mg} / \mathrm{l}$ kanamycin, $10 \mathrm{ng} / \mathrm{ml}$ epidermal growth factor, equine chorionic gonadotropin (eCG), $10 \mathrm{IU} / \mathrm{ml}$ human chorionic gonadotropin (hCG), and $10 \%(\mathrm{v} / \mathrm{v})$ porcinefollicular fluid $(\mathrm{pFF})$ at $39^{\circ} \mathrm{C}$ in a humidified atmosphereof $5 \% \mathrm{CO}_{2}$ for $42-44 \mathrm{~h}$ and donor cell collected from ear skin afghanhound male dog. After somatic cell nuclear transfer (SCNT), embryo development were examined for cleavage rate and $144 \mathrm{hr}$ for final development after cultured in media. The result shows that, amino acid and b-mercapoethanol addition in culture medium (NCSU-23) have no effect on embryo development. The development rate of embryo until 16 cell stage in NCSU and NCSU supplement are $4.67 \%$ and morula stageare $3.73 \%$ and $4.67 \%$.
\end{abstract}

Key words : intergeneric clone embryo, canine, b-mercaptoethanol (b-ME), amino acid (AA)

\section{Introduction}

Interspecies somatic cell nuclear transfer method was firstly applied for conservation of endangered animals. The highly publicized that an adult sheep had been cloned from the nucleus of a frozen somatic cell (Wilmut et al., 1997) speculated that cloning technologies might be applied to increase population sizes of endangered species, or even restore them following extinction (Cohen, 1997; Wen et al., 2005).

*corresponding author :Yuda Heru Fibrianto, Department of Physiology, Faculty of Veterinary Medicine, Gadjah Mada University, JI. Olahraga Karang Malang, Yogyakarta, 55281, Indonesia, Tel. 62274-649-62415; E-mail :yuda@ugm.ac.id
Interspecies nuclear transfer also provides a possible approach to clone animal species whose oocytes were difficult to obtain (Jumnian et al., 2002; Wen et al., 2003). Several studies have shown that oocyte cytoplasm from bovine, rabbits and sheep can support early development of embryos produced by nuclear transfer of somatic cells nuclei from various mammalian species (Dominko et al., 1999; White et al ., 1999; Cohen et al ., 1999; Lanza et al., 1999; Chen et al., 1999; 2002; Wen et al., 2003). Recently, thesuccesses of cloning gaur (Lanza et al., 2000) and mouflon (Loi et al., 2001) have demonstrated that the technique of interspecies cloning can be practically applied to save highly endangered species, such as the giant panda, Ovis orientalis musilmon, buffalo, bos gaurus (White et al., 
1999; Lanza et al., 2000; Vogel et al., 2001; Chen et al., 2002; Jumnian et al., 2002; Sansisena et al ., 2005).

The establishment of optimum culture medium for embryos of domestic animals derived from in vitro fertilized (IVF) and somatic cell nuclear transfer (SCNT) is very critical for applied as well as basic research. Many factors are known to influence the in vitro culture (IVC) of mammalian embryos. Among them, media composition, culture atmosphere, temperature, oxygen tension, osmotic pressure, free radical scavengers, volume of culture drops, and embryo manipulation such as microinjection and cryopreservation are reported to be influence embryo development and quality (Quinn and Harlow, 1978; Harlow and Quinn, 1982; Umaoka et al., 1992; Kooyman and Pinkert, 1994; Bagiset al., 2002; Bagisand Odaman, 2004). Factors that have a negative impact on the in vitro development of the embryo include oxidative stress and composition of culture medium (Umaoka et al., 1992).

A mino acids serve a variety of physiological functions, including: the synthesis of proteins and nucleotides (Epstein and Smith 1973; A lexiou and Leese 1992; Katchadourian et al., 1994), nutrition and energy provision (Lane and Gardner, 1997; 1998; Houghton et al., 2002), osmoregulation (Van Winkle and Campione, 1996; Dumoulin et al., 1997; Dawson et al., 1998), protection against oxidative stress (Lindenbaum 1973; NasrEsfahani et al., 1992), pH regulation (Bavister and McKiernan, 1993; Edward et al., 1998), signalling molecule biosynthesis ( $\mathrm{Wu}$ and Morris, 1998), trophectoderm differentiation (Martin and Sutherland, 2001) and basement membrane formation between primitive endoderm and ectoderm (Biggers et al., 2000). Although achievements have made early stages of feasible embryonic development in vitro, the adequate culture conditions for the preimplantation porcine embryo have yet to be determined. Differential developmental competence in response to various culture media has been demonstrated between IVF and SCNT embryos (Chung et al., 2002). Four-cell developmental block was overcome by using NCSU-23 in vivo porcine oocytes (Machaty et al ., 1998).

Glutathione is the major non-protein sulfidryl compound present in mammalian cells. Multiple actions have been described for $\mathrm{GSH}$, including increasing amino acid transport, stimulating DNA and protein synthesis, reduction of disulfides and protection against toxic effects of oxidative damage(M eister, 1983; Lafleur et al., 1994). It has been demonstrated that adding beta mercaptoethanol (b-ME) increased intracellular GSH in themo uselymphocytes (Zmuda and Friedenson, 1983). In mouse embryo, it was reported that glutathione content decreases about tenfold during preimplantation development and later stage embryos would be more sensitive to oxidative stress because of their lower GSH content (Nasr-Esfahani and Johnson, 1992). As for embryotrophic effect of b-ME in embryos, Takahashi et al. (1993) demonstrated that theadding low molecular weight thiolssuch â-ME and cysteamineinto culture medium enhanced cysteine mediated GSH synthesis and improved the production of 6- to 8-cell bovine embryos in vitro. In addition to this, increased intracellular GSH content in oocytes and embryos of varied developmental stages improves embryonic development and embryo quality, resulting in higher blastocyst yield (Takahashi et al., 1993). The results obtained by Bagis and Odaman (2004a) demonstrated that the combined treatment of b-ME and amino acid to 1-cell stage embryos not only enhanced in vitro development to the blastocyst stage but also improved both the number of blastocyst 
cells and livefetuses in mouse.

Although studies have reported using mouse embryos, in intergeneric canine cellnuclear transfer embryo culture, the effect of b-ME and AA supplement in culture medium on embryo development is largely not known. Therefore, thepresent study was conducted to examinethe efficacy of NCSU23 medium supplemented with b-ME and AA on the developmental competence of intergeneric canine embryo using porcine oocyte in order to improve in vitro culture conditions.

\section{$M$ aterials and $M$ ethods \\ Collection of porcine oocytes and invitro maturation (IVM)}

Ovaries were obtained from a local abattoir and transported to thelaboratory in physiological saline at 30 to $35 \mathrm{C}$. Antral follides 3 to $6 \mathrm{~mm}$ in diameter were aspirated using an 18-gaugeneedle attached to a 5-ml disposable syringe. Cumulusoocyte complexes (COCs) with compact cumulus cells were collected from the aspirate and washed several times in HEPES-buffered tissue culture medium (TCM)-199 (Life Technologies, Rockville, MD, USA). The COCs were then placed in IVM medium (Earle's salts- and Lglutamine-containing TCM-199 supplemented with $26.2 \mathrm{mM} \mathrm{NaHCO}, 3.05$ $\mathrm{mM}$ glucose, $0.91 \mathrm{mM}$ sodium pyruvate, 0.57 mM L-cysteine, $75 \mathrm{mg} /$ I kanamycin, 10 $\mathrm{ng} / \mathrm{ml}$ epidermal growth factor (SigmaAldrich), equine chorionic gonadotropin (eCG, Intervet, Boxmeer, Netherland), 10 $\mathrm{IU} / \mathrm{ml}$ human chorionic gonadotropin (hCG, Intervet Boxmeer Netherland), and $10 \%$ ( $\mathrm{v} / \mathrm{v}$ ) porcinefollicular fluid (pFF). The pFF was aspirated from superficial antral follicles 8 to $10 \mathrm{~mm}$ in diameter from prepubertal gilts. After centrifugation at $1,600 \times \mathrm{g}$ for $30 \mathrm{~min}$, supernatant was collected and filtered sequentially through $1.2 \mathrm{~mm}$ and $0.45 \mathrm{~mm}$ syringefilters (Gelman
Sciences, Ann Arbor, MI, USA). Prepared pFF wasthen stored at-20C until use.

A group of 50 COCs was cultured in 500 $\mathrm{ml}$ IVM medium at $39^{\circ} \mathrm{C}$ in a humidified atmosphere of $5 \% \mathrm{CO}_{2}$ and $95 \%$ air. After culturing for $22 \mathrm{hr}$, COCsweretransferred to eCG- and hCG-free IVM medium and cultured further for 20-22 h. At theend of the culture, oocytes were freed from cumulus cells by repeated pipetting in IVM medium containing $0.1 \%$ hyaluronidase. Oocytes with a first polar body, intact zona pellucida, evenly granulated cytoplasm, expanded cumulus cells and distinct ooplasmic membrane were provided for SCNT of this study.

\section{Preparation of recipient oocytes for somatic} cell nuclear transfer

After $42-44 \mathrm{~h}$ of maturation, the oocytes were freed from cumulus cell by pipetting in HEPES-buffered NCSU-23 medium supplemented with $0.1 \%$ hyaluronidase. Oocytes were cultured in NCSU-23 containing $5 \mathrm{mg} / \mathrm{ml}$ bisbenzimide (Hoechst 33342; Sigma-aldrich Co.) and $7.5 \mathrm{mg} / \mathrm{ml}$ cytochalasin B for 30 min. Oocytes were placed in a $4 \mathrm{ml}$ drop of HEPES-buffered NCSU-23 medium on working dishes. Each recipient oocyte was held with a holding micropipette (110 $\mu \mathrm{m}$ in outer and $24 \mu \mathrm{m}$ in inner diameter) and zona pellucida was partially dissected with a fine glass needleto create a slit near the polar body. Then, the first polar body and adjacent cytoplasm containing metaphase plate were removed by squeezing. Enucleated oocyte were visually verified by ultraviolet fluorescence, keeping exposure to a minimum. The enucleated oocytes were then placed in NCSU 23-D (Table 7) and used for SCNT.

\section{Injection, Electrofusion and activation}

Injection was performed in $4 \mathrm{ml}$ drop of HEPES-buffered NCSU23-W medium and covered with light mineral oil. A single cell 
with smooth membranewas transferred into the perivitelline space of an enucleated oocyte. Before nudear transfer, transfected donor cell were identified emission of greenfluorescence under an epifluorescent microscope using a standard fluorescein isothiocyanate (FITC) filter set. Roundshaped and green-colored small cell were individually injected into perivitellinespace of enucl eated oocytes.

Reconstructed oocytes were fused and activated simultaneously. The reconstructed oocytes were equilibrated for 10 sec in fusion medium $\left(0.26 \mathrm{M}\right.$ mannitol, $0.1 \mathrm{mM} \mathrm{MgCl}{ }_{2}, 0.1$ $\mathrm{mM} \mathrm{CaCl}, 0.5 \mathrm{mM}$ HEPES and $0.05 \%$ BSA, Table 3) and transfer to a fusion chamber with two electrodes (3.2 mm gap, BTX Inc., San Diego, CA ) overlaid with the mannitol medium. Reconstructed oocytes (5-7 oocytes) were aligned with a fine mouthcontrolled Pasteur pipette in parallel with a fusion chamber.

Fusion was induced with a single DC pulse of $1.86 \mathrm{kV} / \mathrm{cm}$ for 30 , by on a Electrocell Manipulator 2001 (BTX Inc.). All treated oocytes were washed three times with NCSU23-W supplemented with $4 \mathrm{mg} / \mathrm{ml}$ BSA, placed in $25 \mathrm{ml}$ microdrops (10-15 oocytes per drop) of NCSU23-D under mineral oil and cultured at $39 \mathrm{C}, 5 \% \mathrm{CO}_{2}, 5 \%$ $\mathrm{O}_{2}$ and $90 \% \mathrm{~N}_{2}$. Fused oocytes were determined one hour after the electrical pulseunder microscope.

\section{Subsequent culture}

The reconstructed embryos were cultured in $25 \mathrm{ml}$ drops of NCSU23-D overlaid with mineral oil at $39^{\circ} \mathrm{C}$ in humidified $5 \% \quad \mathrm{CO}_{2}, 5 \% \mathrm{O}_{2}$ and $90 \% \mathrm{~N}_{2}$ atmosphere. Ten to fifteen embryos were cultured together. Cleavage rate was recorded after $48 \mathrm{~h}$ post fusion. On 7 days post fusion, the development of reconstructed embryos was recorded, and GFP expression rate in embryo was examined under FITC filter.

\section{Preparation of donor caninecells}

Canine fibroblast cells were isolated from ear skin. The external surface of canine ear skin was shaved and cleaned aseptically. A piece of ear skin tissueabout $100 \mathrm{~mm}^{3}$ wide and $2 \mathrm{~mm}$ thick was biobsied and immediately immersed in D-PBS (Life technologies). After washing, the tissues wereminced by a surgical bladeon a $100 \mathrm{~mm}$ culture dish, followed by dissociation by $0.25 \%$ (w/ v) trypsin containing $1 \mathrm{mM}$ EDTA for 1 to $2 \mathrm{~h}$ at $38^{\circ} \mathrm{C}$. Trypsinized cells were washed once by centrifugation (300xg, 2 $\mathrm{min}$ ) and subsequently seeded into $100 \mathrm{~mm}$ culture dishes and cultured for 6-8 day in Dulbecco's modified Eagle medium (DMEM) supplemented with $10 \%$ (v/ v) fetal bovineserum (FBS), $1 \mathrm{mM}$ sodium pyruvate, $1 \%(\mathrm{v} / \mathrm{v})$ non-essential amino acid and 10 $\mathrm{ml} / \mathrm{ml}$ penicillin/ streptomycin solution in a humidified atmosphere of $95 \%$ air, $5 \% \mathrm{CO}_{2}$ at $38^{\circ} \mathrm{C}$ before removal of unattached clumps of cells or explants. The attached cells were passageby trypsinization when confluent.

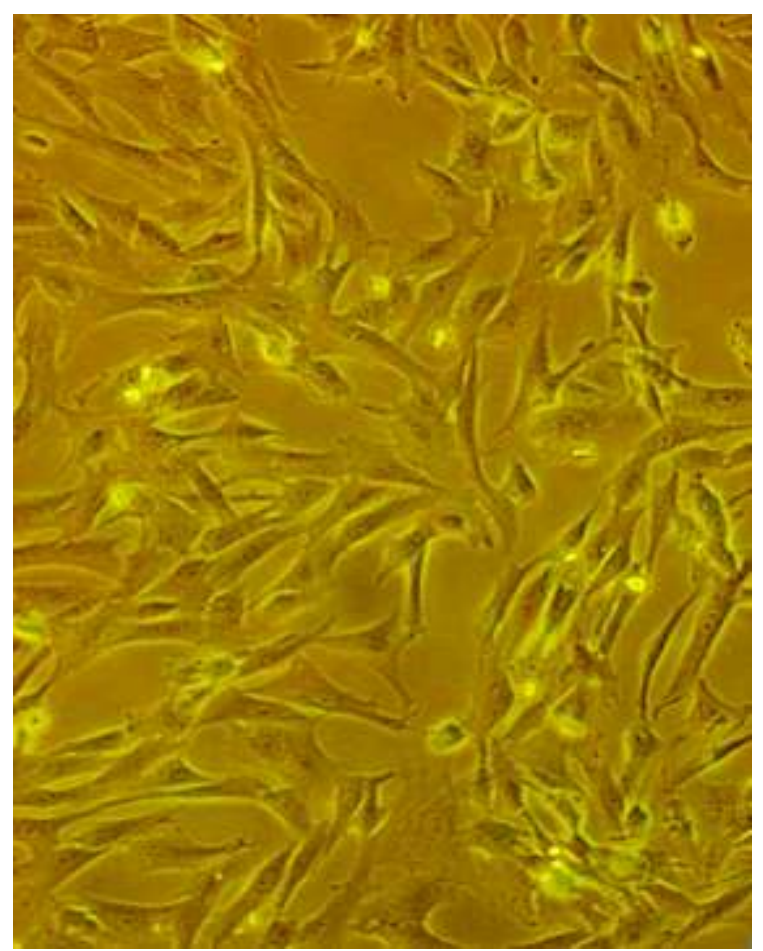

Figure 1. A dult canine ear skin fibroblast cell line 


\section{Statistical analysis}

Data from all experiment in this experiment were analyzed using the statistical Analysis System (SAS) program. Data were subjected to analysis of variance (ANOVA) and protected least significant different (LSD) test to determine differences among experimental groups. When a significant model effect was found in each experimental parameter, data were compared by the least squares method. Statistical significance was determined whereP valuewasless than 0.05 .

Table 1. Composition of North Carolina State University (NCSU)-23medium

\begin{tabular}{|c|c|c|}
\hline Ingredient & $\begin{array}{l}\text { NCSU23-W } \\
\text { (mmoln) }\end{array}$ & $\begin{array}{l}\text { NCSU22-D } \\
\text { (mmol/2) }\end{array}$ \\
\hline $\mathrm{NoCl}$ & 108.73 & 108.73 \\
\hline $\mathrm{KCl}$ & 4.78 & 4.78 \\
\hline $\mathrm{CaCl}_{2}$ & 1.70 & 1.70 \\
\hline $\mathrm{KH}_{2} \mathrm{PO}_{4}$ & 1.19 & 1.19 \\
\hline $\mathrm{MgSO}_{4}+7 \mathrm{H}_{2} \mathrm{O}$ & 1.19 & 1.19 \\
\hline $\mathrm{NaHOOO}$ & 4.01 & 25.07 \\
\hline Glucose & 5.55 & 5.55 \\
\hline Glutamine & 1.00 & 1.00 \\
\hline Taunne & - & 7.00 \\
\hline Hypotaurine & - & 5.00 \\
\hline L-Cysteine & - & - \\
\hline HEPES1 & 10,00 & - \\
\hline Kanamycin? & $75 \mathrm{mg} / \mathrm{L}$ & $75 \mathrm{mg} / \mathrm{L}$ \\
\hline $\left.\mathrm{BSA} / \mathrm{mg} / \mathrm{mL}^{-1}\right)^{\mathrm{s}}$ & 4.0 & . \\
\hline
\end{tabular}

\section{Experimental studies}

Effect of amino acid and ß-mercaptoetanol supplement on NCSU-23 on intergeneric canine embryo development with porcine oocytecytoplasm recipient

Canine intergeneric embryos with porcineoocytecytoplasm recipient cultured in different media with randomly distribution. Embryo development were examined for cleavage rate and $144 \mathrm{~h}$ for final development after cultured in media.

\section{Results}

In this experiment, amino acid and ßmercapoethanol addition in medium NCSU-
23 have no effect on embryo development (Tabel 2). The development rate of embryo until 16 cell stage in NCSU and NCSU supplement are $4.67 \%$ and 4.67 respectively and morulastageare $3.73 \%$ and $4.67 \%$.

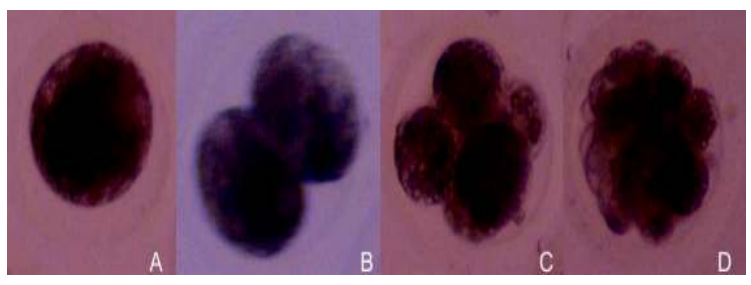

Figure 2. Development of intergeneric cloned embryo (zygote/ 1 cell (A); 2 cell (B); 6 cell (C), morula (D) using porcineoocyterecipient.

\section{Discussion}

The aim of this study was wanted to learn about good supporting media culture for optimal development of intergeneric cloned dog embryo using porcine oocyte as cytoplasm donor. In this study we used NCSU-23 or NCSU-23 plus BME and amino acid.

Thesupplementation of amino acids to a culture medium significantly improved the development of hamster (Schini and Bavister, 1988), mouse (Lane and Gardner, 1994; Lamb and Leese, 1994; Lane and Gardner, 1997), and cow embryos (Rosenkrans and First; 1994; Bavister and Arlotto, 1990; Bavister and Mckiernan, 1993). It has al so been suggested that in vitro produced embryos should be exposed to amino acids as early as the oocyte stage, as this increases oocyte maternal mRNA levels and promotes preimplantation development (Watson et al., 2000). In support of this opinion, it is notable that a brief exposure of zygotes to amino acid-free conditions depresses their developmental capacity and blastocyst cell numbers (Gardner and Lane,1996).

In bovine, a major step toward ameliorating media for cultureembryos was discovery that the addition of Eagle's amino 
acids improved embryo development (Takahashi and First, 1992; Kim et al., 1993; Gardner 1994; Rosenkrans and First; 1994). Much of understanding of the way that amino acids affect mammalian embryo development and subsequent viability has come from studies on the hamster (Carney and Bavister, 1987; Bavister and Arlotto, 1990; Bavister and Mckiernan, 1993; Mckiernan et al., 1995), mouse (Mehta and Kiessling, 1990; Gardner and Lane, 1993; 1996; Lane and Gardner, 1994; 1997; 1997a), and rat ( Zhang and A rmstrong, 1990). These studies have determined that amino acids can be either stimulatory or inhibitory to embryo development in vitro and that the presence of amino acids in culturemedia has a significant effect on the viability of embryos and postimplantation development.

On the other hand, low molecular weight thiol compounds, such asb-ME, have been reported to reduce cystine to cysteine and also to promote the uptake of cysteineenhancing glutathione synthesis (Takahashi et al., 2002). Moreover, it has been reported that b-ME transports cystine, forming a mixed disulphide that is taken up to facilitate the uptake of cysteine into the cells (Ishii et al., 1981). Data on the effect of the concentration of b-ME are conflicting. In a study of A beydeera et al . (1998) reported that adding 0 to $50 \mu \mathrm{M}$ b-ME during in vitro maturation of pig oocytes increased intracellular glutathione concentration and subsequent embryo development and blastocyst cell numbers. The concentration $(10 \mu \mathrm{M})$ of b-ME used in the present study was different from that $(50 \mu \mathrm{M})$ reported by Takahashi et al ., (1993) but it was the sameas that reported by Hamano et al., (1997) (10 to $50 \mathrm{mM}$ ). Glutathione has many important functions in cells or embryos for the mechanism of cell defense during oxidative stress and toxicants (Gardner et al., 2000). It is possi ble that GSH synthesis in embryos was increased by addition both of b-ME and AA into NCSU-23 medium and will be resulted in higher blastocysts and total cell numbers than that of control group.

A mino acids and b-ME both can play a vital role for preventing the oxidative stress of embryo (Ishii et al., 1981; Issels et al., 1988; H amano et al ., 1994; Reed, 1994; Gardner and Reed, 1995; 1995a; Lane and Gardner, 1997; Takahashi et al., 2002). There is a positive correlation between glutathione (GSH) and oxidative stress of the embryo. Glutathione is a tripeptide thiol synthesized by glutamic acid, cysteine, and glycine in pathway of the glutamyl cycle (Abeydeera et al., 1998; Gardner et al ., 2000). Most cells do not take GSH intact from outside the cell; instead, GSH is broken down at the cell membrane, the constituent $A A$ are taken up, and GSH is resynthesized inside the cell or the AA are used for other pathways (Reed, 1994). It has been reported that during IVC, GSH level drops approximately ten fold beginning from the unfertilized oocyte to blastocyst stage in mouse (Gardner and Reed, 1994; 1995). The availability of precursor AA is a regulatory factor in GSH synthesis, and it is likely that AA supplied from outside the cell provide a control point in mammalian cells (Issels et al., 1988). It has been reported that nonessential AA and glutamine accelerate the time of the first three cleavage divisions and increase the time of the first three cleavage divisions and increase the time of compaction in the mouse when added to culture medium (Lane and Gardner, 1997). In another findings observed that NEAA improves development during cleavage, whereas EAA supports development after 8 cell stage(Van Winkleand Dickinson, 1995)

Unfortunately, the in vitro embryo culture media used in this study does not 
supported the intergeneric embryo until blastocyst stage development, just a few morullastages development and thereare 16 block development problem, although the media used for IVC are widely used for IVC for various mammalian species (Wen et al., 2003). In this study we used media which usually we used as donor cytoplasm (NCSU23) and also subsequent development is dependent on successful transfer of control to the embryonic genome, which may be deficient in embryos produced by somatic nuclear transfer. Establishment embryos from different mammalian species require species-specific embryo culture conditions (Leibfried-Rudledge et al., 1997). The ability of N CSU to supportembryonicdevelopment of interspecies units may be attributable to the fact that this initial development of embryo is driven by recipient cytoplasm, and also thus any media supporting bovine and porcine embryo development might also support the initial development of interspecies NT embryos. A nother morphological features that characterize the time of the transition is a developmental block in non permissive in vitro culture conditions (Crosby et al., 1988), embryos reconstructed by SCNT aremoresusceptible to suboptimal culture condition than IVP embryos, indicating a need to improve culture formulations to enhance development of these compromised embryos which may have abnormal metabolicactivities (Chung et al., 2002).

It means that embryo from different mammalian species require species-specific culture media. Yong et al. (2003) demonstrated that the interspecies nuclear transfer embryo (macaca fibroblast cell and rabbit oocyte) have been block at 4 cell development stage when used media for rabbit embryo culture and reached the blastocyst stage when culture in media which matched with macaca embryo. A nother research with Canine cell with bovine oocyte recipient in SOF medium got $0.4 \%$ blastocyst although the number of blastocyst cell only 50 (Murakami et al., 2005).

These indication told that, for in vitro culture canine embryo, NCSU-23 are suboptimal for embryo development although for several mammalian these media supported the development (Rosenkrans, 1998; Biggers, 2000) and improvement culture system for the development of canine embryo still necessary.

Table 2. Effect of amino acid and â-mercaptoetanol supplementation in NCSU-23 medium on canine embryo development with porcine oocyte cytoplasm recipient

\section{Acknowledgment}

This study was done in Laboratory of Theriogenology and biotechnology, College of Veterinary Medicine Seoul National University. The authors acknowledge to my professor, Hwang Woo-Suk PhD, Lee Byeong-Chun, PhD and Kang Song-Keun PhD for their supporting my study in this laboratory.

\section{References}

A beydeera LR, Wang WH, Cantley TC, Prather RS, Day BN .1998. Presence of mercaptoethanol can increase the glutathione content of pig oocytes matured in vitro and the rate ofblastocyst devel opment after in vitro fertilization.theriogenology,50,747-56.

Bagis H, Odaman M.H. 2004. Effect of chemically defined culture medium 
supplemented with a mercaptoethanol and amino acids on implantation and development of different stage in vivo- or in vitroderived mouseembryos. Mol. Reprod. Dev.,69,52-59.

Bavister BD, Arlotto T. 1990. Influence of singleamino acids on the development of hamster 1-cell embryos in vitro. Mol. Reprod. Dev.,25,45-51.

Biggers, J.D., McGinnis, L., and Raffin, M., 2000. A mino acids and preimplantation development of the mouse in protein-free potassium simplex optimised medium. Biol. Reprod., 63,281-293

Chung YG, Mann MR, Bartolomei MS.2002. Nuclear-cytoplasmic"tug of war" during cloning: effects of somatic cell nuclei on culture medium preferences of preimpplantation cloned mouse embryos. Biol Reprod ; 66:1178-1184

Crosby IM, Gandolfi F, Moor RM.1988. Control of protein synthesis during early cleavage of sheep embryos. J Reprod Fertil ,82,769-775

Dawson KM, Collins JL, Balt JM.1998. Osmolarity-dependent glycine accumulation indicates a role for glycine as an organic osmolytein early preimplantation mouse embryos. Biol. Reprod.,59,225-232

Dominko T, Mitalipova M, Haley B. 1999. Bovine oocyte cytoplasm supports development of embryos produces by nuclear transfer of somatic cell nuclei from various mammalian species. Biol reprod.,60, 1496-1502.

Edwards LJ, Williams DA, Gardner DK.1998.Intracellular pH of the mouse preimplantation embryo: amino acids act as buffers of intracellular $\mathrm{pH}$. Human Reproduction, 13, 3441-3448
Epstein CJ, Smith SA. 1973. Amino acid uptake and protein synthesis in preimplantation mouse embryos. Devel opmental Biology,33,171-184.

Gardiner CS, Reed, DJ.1995.Synthesis of glutathione in the preimplantation mouse embryo. Arch Biochem. Biophys., 318, 30-36.

Gardner, D.K., Lane, M.W., and Lane, M., 2000. EDTA stimulates cleavage stage bovine embryo development in culture but inhibits blastocyst development and differentiation. Mol. Reprod. Dev., 57,256-261.

Gardner, D.K., and Lane, M., 1996. Alleviation of the "2-cell block" and development to the blastocyst of CF1 mouse embryos: role of amino acids, EDTA and physical factors. Hum. Reprod., 11, 2703-2712

Hamano S, Kuwayama M, Takahashi M, Okamura, N, Okano A, Nagai T.1994. Effect of â-mercaptoethanol on the preimplantation development of bovine embryos fertilized in vitro. J. Reprod.Dev.,40,355-59.

Ishii TS, Bannai S, Sugita Y. 1981.Mechanism of growth stimulation of $L 1210$ cells by 2-mercaptoethanol in vitro. J. Biol. Chem.,256,12387-12392.

Issels RD, Nagele A, Eckert KG., Wilmanns W. 1998. Promotion of cystine uptake and its utilization for glutathione biosynthesis induced by cysteamine and $\mathrm{N}$-acetyl-cysteine. Biochem. Pharmacol.,40,355-59.

Jumnian S, Kanok P, Mayurachat J and Yindee K.2002. Xenonuclear transplantation of buffalo (Bubalus bubalis) fetal and adult somatic cell nuclei into bovine(Bos indicus) oocyte cytoplasm and their subsequent development. Theriogenology, 57,18291837. 
Katchadourian C, Joly C, Menezo Y.1994. Interactions in glycine and methionine uptake, conversion and incorporationinto proteins in the preimplantation mouse embryo. Zygote.,2,301-306.

Lafleur MVM, Hoorweg JJ, Westmijze EJ, Retel J. 1994. The ambivalent role of glutathione in the protection of DNA against singlet oxygen. Free Rad. Res., 21,9-17.

Lane M, Gardner DK. 1997.N on essential amino acids and glutamine decrease the time of the first three cleavage divisions and increase compaction of mousezygotes in vitro. J Assist Reprod Genet.,4,398-403.

Lanza RP, Civelli JB and Diaz F. 2000. Cloning of endangered species (bos gaurus) using interspecies nuclear transfer. Cloning.,2, 79-90.

Leibfried-Rutledge ML, Dominko T, Critser ES and Critser JK. 1997. Tissue maturation in vivo and in vitro: gamete and early embryo ontogeny. In: Karow AM, Critser JK (eds.), Reproductive Tissue Banking. New York: Academic Press; : 23-137.

Loi P, Ptak G, Barbony B, Fulka JJr, Cappai P and Clinton M. 2001.Genetic rescue of endangered mammals by crossspecies nuclear transfer using post mortem somatic cells. N ature Biotech. , 19,962-964

Macháty Z, Day BN, Prather RS.1998. Development of Early Porcine Embryos In Vitro and In Vivo. Biol. Reprod.,59,451-455.

Martin PM, Sutherland AE. 2001. Exogenous amino acids regulate trophectoderm differentiation in the mouse blastocyst through an mTOR-dependent pathway. Developmental Biology.,240,182-193.
Murakami $M$, Otoi $T$, Wongsrikeao $P$, Agung B, Sambuu R, Suzuki T.2005. Development of interspecies cloned embryos in yak and dog. Cloning Stem Cells.,7(2),77-81.

Nasr-Esfahani MH, Johnson MH.1992. Quantitative analysis of cellular glutathione in early preimplantation mouse embryos developing in vivo and in vitro. Hum. Reprod., 7,1281-90.

Rosenkrans CFJ, First NL.1994.Effect of free amino acids and vitamins on cleavage and developmental rate of bovine zygotes in vitro. J. Anim. Sci.,72,434-437.

Sansinena MJ, Hylan D, HebertK, Denniston RS and Godke RA. 2005. Banteng (Bos javanicus ) embryos and pregnancies produced by interspecies nuclear transfer. Theriogenology, 63,1881-1091

Takahashi M, Nagai T, Hamano S, Kuwayama M, Okamura N, Okano A.1993. Effect of thiol compounds on in vitro development and intracellular glutathione content of bovine embryos. Biol. Reprod.,49,228-32.

Takahashi M, Nagai T, Okamura N, Takahashi H, Okano A. 2002.Promoting effect of $\hat{a}$ mercaptoethanol on in vitro development under oxidative stress and cysteine uptake of bovine embryos. Biol. Reprod.,6,562-67.

Takahashi Y, First NL. 1992. In vitro development of bovine one-cell embryos: influence of glucose, lactate, pyruvate, amino acids and vitamins. Theriogenology,37,963-978.

Umaoka Y, Noda Y, Narimoto K, Mori T.1992. Effects of oxygen toxicity on early development of mouse embryos. Mol. Reprod. Dev.,31,28-33.

Van Winkle LJ, Campione AL. 1996.Amino acid transport regulation in 
preimplantation mouse embryos: effect of amino acid content and preand peri-implantation development. Theriogenology,45,69-80.

Vogel G. 2001.Endangered species. Cloned gaur a short-lived success. Science, 291,409

Watson AJ, De Sousa P, Caveney A, Barcroft LC, Natale D, Urquhart J, Westhusin ME. 2000.Impact of bovine oocyte maturation media on oocytetranscript levels, blastocyst development, cell number, and apoptosis. Biol. Reprod.,62,355-364.

Wen DC, Bi CM, Xu Y, Yang CX, Zhu ZY, Sun QY and Chen DY.2005. Hybrid embryos produced by transferring Panda or Cat somatic nuclei into Rabbit MII oocytes can developmental to blastocyst in vitro. J of exp zo0., 303A, 689-697.

Wen DC, Yang CX, Cheng Y, Li JS, Liu ZH, Sun QY, Zhang JX, Lei L, Wu YQ, Kou ZH and Chen DY. 2003. Comparison of developmental capacity for intra and inter-species cloned cat (felis catus) embryo. M ol. Reprod. D ev., 66, 34-45

WhiteKL, Bunch TD, Mitalipov S, Reed WA. 1999. Establishment of pregnancy after thetransfer of nuclear transfer embryo produced from the fusion or argali (O vis ammon) nuclei into domestic sheep (0 vis aries) enucleated oocyte. Cloning, 1,47-54

Wilmut I, Schnieke AE, McWhir J, Kind AJ, Campbell KHS. 1997. Viable offspring derived from fetal and adult mammal ian cells. $N$ ature, 385,810-813

Wu G, Morris SM. 1998. Arginine metabolism: nitric oxide and beyond. Biochemical Journal, 336, 1-17.

Yang, C.X., Han, Z.M., Wen, D.C., Sun, Q.Y., Zhang, K.Y., Zhang, L.S., Wu, Y.Q., Kou, Z.H., and Chen, D.Y., 2003. In vitro development and mitochondrial fate of macaca-rabbit cloned embryos. M ol Reprod D ev, 65,396-401

Zhang X, Armstrong DT. 1990.Presence of amino acidsand insulin in a chemically defined medium improves development of 8-cell rat embryos in vitro and subsequent implantation in vivo. Biol Reprod.,42(4),662-8.

Zmuda J, Friedenson B. 1983. Changes in intracellular glutathione levels in stimulated and unstimulated lymphocytes in the presence of 2mercaptoethanol or cysteine. J. Immunol.,130, 362-64. 